\title{
Irrigated agriculture for food self-sufficiency in the sub-Saharan African region
}

\author{
Ransford Opoku Darko ${ }^{1,2}$, Junping Liu ${ }^{1 *}$, Shouqi Yuan ${ }^{1}$, \\ Livingstone K. Sam-Amoah" ${ }^{2}$, Haofang Yan ${ }^{1}$ \\ (1. Research Centre of Fluid Machinery Engineering and Technology, Jiangsu University, Zhenjiang 212013, China; \\ 2. Department of Agricultural Engineering, University of Cape Coast, Central Region, Cape Coast, PMB Ghana)
}

\begin{abstract}
Increasing agricultural productivity in Africa will have important impacts not only on the agricultural sector but also can be a catalyst for industrialization through agro-processing. Irrigation, therefore, has a crucial role in enhancing food security and reducing hunger in the region. Numerous countries in Africa consider water and irrigation management as a key factor in improving their food security and ensuring access to drinking-water for their populations. Fortunately, there is evidence from a number of places on the continent where the adoption of efficient irrigation systems has led to higher productivity among smallholder farmers. While the appropriate interventions for the diverse agro-ecological zones of sub-Saharan Africa are known, adoption among smallholder farmers still remains a challenge. Digital technology opens the vast untapped potential for farmers, investors, and entrepreneurs to improve the efficiency of food production and consumption in Africa. From precision farming to an efficient food supply chain, technology could bring major economic, social, and environmental benefits. Increasing investment and involvement of the private sector is crucial for the up-scaling of irrigation technologies. Indeed, the sheer optimism across the startup ecosystem is that extreme hunger can be cured in Africa, in this generation, by significantly transforming the industry that employs most of its citizens. This paper draws on lessons from past trends in the irrigation industry and emphasizes on novel directions to ensure that farmers, as well as other stakeholders reap the benefits associated with improved technologies.
\end{abstract}

Keywords: food self-sufficiency, irrigation development, small-holder farms, sub-Sahara Africa, sustainability DOI: $10.25165 /$ j.ijabe.20201303.4397

Citation: Darko R O, Liu J P, Yuan S Q, Sam-Amoah L K, Yan H F. Irrigated agriculture for food self-sufficiency in the sub-Saharan African region. Int J Agric \& Biol Eng, 2020; 13(3): 1-12.

\section{Introduction}

Irrigation is critical to both food production and food security. Over the past decades, significant advances have been made in irrigation efficiency in technologies such as low-pressure center pivot sprinkler systems or sub-surface drip irrigation systems, small motorized pumps, drip kits, treadle pumps, rope and washer pumps in the sub-Saharan African (SSA) region. However, challenges remain and still reveal more opportunities for continued improvements in water use efficiency through the application of situation-appropriate efficient technologies (high untapped irrigation potential; rainwater harvesting to improve water availability, low-cost irrigation technologies adaptable to local conditions; traditional schemes rehabilitation) and other management practices (high commitment of national governments, NGOs and donors to smallholder irrigation expansion). The

\section{Received date: 2019-05-15 Accepted date: 2020-03-29}

Biographies: Ransford Opoku Darko, Research fellow, research interests: water saving irrigation, agricultural water management, sustainable agriculture. Email: chiefrodark@yahoo.com; Shouqi Yuan, Professor, research interests: CFD of pumps, fluid machinery, irrigation systems, Email: shouqiy@ujs.edu.cn; Livingstone K. Sam-Amoah, Professor, research interests: Soil and water engineering, Email: 1k_samamoah@yahoo.com; Haofang Yan, Associate Professor, research interests: water saving irrigation theory and technology, agricultural water management; Email: yanhaofang@yahoo.com.

*Corresponding author: Junping Liu, Associate Professor, research interests: CFD of pumps, fluid machinery, irrigation systems. Research Centre of Fluid Machinery Engineering and Technology, Jiangsu University, Zhenjiang 212013, China. Tel: +86-13914555629, Email: liujunping401@ 163.com. majority of SSA countries are stricken by food shortages and undernourishment, with much of the population lacks reliable access to food supplies and basic dietary requirements. Africa's future is closely linked to its demographic changes, demanding due attention: both towards reducing extreme fertility; and to the adaptation to the rapid expansion of middle-age population strata in response to growing life expectancy. Most regions cannot expect long-term food self-reliance, making national economic planning essential to secure an industrial development for generating necessary foreign currency. Despite a marked growth in global food production in the past half-century, more than one in seven people today still do not have access to basic dietary requirements and sufficient protein and energy input ${ }^{[1]}$. Africa remains dependent on food imports unable to feed its people on domestic production alone. Escalating food costs have pushed levels of import expenditure to the breaking point. Only one-third of African countries have enough agriculture export revenue to pay for food imports bills while total food imports are increasing on average at $3.4 \%$ a year. Although Africa has abundant land and water resources, food insecurity is a common problem and importing food not only drains limited national budgets but can have a negative effect for low-income households who struggle to buy basic food items. Pockets of severe food insecurity continue to pose challenges to African governments in the Sahel, the Horn of Africa and the Democratic Republic of the Congo, and food often becomes a weapon of war. According to Spielman et al. ${ }^{[2]}$, South Asia and sub-Saharan Africa are the regions most affected by unreliable food access and undernourishment with $30 \%$ of world 
hunger concentrated in the latter region alone ${ }^{[3]}$. Irrigation in Africa has not developed to the same extent as in Asia hence smallholder irrigation expansion would significantly increase agricultural production, and reduce food insecurity and poverty levels.

Experience in sub-Saharan Africa (SSA) has shown that successful smallholders generally use simple technologies and have secure water supplies over which they have full control. The most successful technologies are those that improve existing farming systems rather than those that introduce radically new ideas. A wide range of well-established traditional technology options is available for use by smallholders including water harvesting, swamp irrigation, spate irrigation, flood plain irrigation using seasonal water and shallow aquifers, hill irrigation, and groundwater irrigation. There is still, however, considerable room to improve and adapt these traditional technologies to different circumstances. In recent years there has been a growing interest in new technologies to carry and apply water. These usually cost much more than traditional methods and rely very much on external specialist support from suppliers and distributors. Distribution technologies such as trickle and sprinkle irrigation and piped supplies for the more traditional surface methods can help farmers to manage their water better as well as reducing wastage. All these technologies have the potential to raise the productivity of water and labor. But they are really only accessible to those farmers who can afford to buy them and who are growing cash crops such as vegetables, fruits and flowers. They are unlikely to be taken up by poor farmers.

Precise irrigation may not be as important to smallholders as it is to farmers in the developed world. This depends on how much precision is lost and it may well be that low-cost systems, although not perfect, are far better at applying water than the other methods used by farmers. The farmer's ability to manage the irrigation application properly is more important than worrying about some of the system's technical shortcomings. The concept of precision agriculture first emerged in the United States in the early 1980s. In 1985, researchers at the University of Minnesota varied lime inputs in crop fields. It was also at this time that the practice of grid sampling appeared (applying a fixed grid of one sample per hectare). Towards the end of the 1980s, this technique was used to derive the first input recommendation maps for fertilizers and $\mathrm{pH}$ corrections. The use of yield sensors developed from new technologies, combined with the advent of GPS receivers, has been gaining ground ever since. Today, such systems cover several hectares in the region. In the American Midwest (US), it is associated not with sustainable agriculture but with mainstream farmers who are trying to maximize profits by spending money only in areas that require fertilizer. This practice allows the farmer to vary the rate of fertilizer across the field according to the need identified by GPS guided Grid or Zone Sampling. Fertilizer that would have been spread in areas that don't need it can be placed in areas that do, thereby optimizing its use. Maintaining the homogeneity of soil nitrogen $(\mathrm{N})$ and plant vigor across agricultural fields is a major concern for farmers and agricultural scheme planners, particularly fields that are irrigated through pressurized systems, such as center pivots $^{[4]}$.

Smartphone and tablet applications are becoming increasingly popular in precision agriculture. Smartphones come with many useful applications already installed, including the camera, microphone, GPS, and accelerometer. There are also applications made dedicated to various agriculture applications such as field mapping, tracking animals, obtaining weather and crop information, and more. They are easily portable, affordable, and have a high computing power ${ }^{[5]}$.

Low-cost technologies refer to modern technologies that have been developed or modified in some way to bring down their cost. An excellent example is the treadle pump, which was developed especially as a low-cost pump for smallholders and continues to be adapted for particular local needs and markets in the region. Low-cost systems of water conveyance and distribution have not been comprehensively tested and evaluated in the region, with the exception of treadle pumps. The adoption by smallholders of treadle pumps to replace the onerous task of lifting and carrying water and the way in which the support services have developed offers lessons for the promotion of other irrigation technologies.

The region is still challenged with rapid population growth which affects the ability of countries to assure a stable supply of and access to food. Despite concerted efforts over the last two decades, the rate of poverty reduction in SSA has been far lower than in other regions of the world. The number of poor people in SSA, living with less than US\$ 1.25 a day, has declined by $23 \%$ between 1993 and 2011 compared to the world average of $59 \%$ during the same period ${ }^{[6]}$.

Therefore, the development of the agricultural sector in this region is central to combating hunger, reducing poverty, and achieving economic growth. However, this cannot be achieved without ensuring a substantial development of surface water and groundwater resources. Irrigation in many SSA countries is dependent on groundwater or run-off-river pumping systems. Transportation of water from main sources to farmer fields is usually done through long unlined channels, which wastes huge amounts of water as percolation losses. Therefore, introducing a low cost and efficient water delivery systems and irrigation technologies that enable farmers to irrigate their small plots and improve water use efficiency can boost crop harvests, farm incomes and nutritional health in deepest pockets of hunger in $\mathrm{SSA}^{[7]}$. The irrigation technologies such as drip and sprinkler systems have the potential to increase the productivity of small-scale irrigation in the SSA region. Sub Saharan Africa (SSA) is water-abundant but uses only $2 \%$ of its total renewable water resources due to lack of water infrastructure ${ }^{[6]}$. Water resources at the regional level do not technically limit irrigation expansion. However, it is restricted due to high investment costs and management complexities. Food production in the region is almost entirely rain-fed with irrigation currently playing a minor role $^{[8]}$. The impact of climate change on crop yields and the social and economic repercussions is another major concern especially in light of the region's high dependence on rainfed agriculture. Except in a few countries of northern Africa, such as Tunisia and Morocco, the potential for irrigation development has not been effectively tapped in Africa. Though SSA has a rich and varied water endowment, only $4 \%\left(6\right.$ million $\left.\mathrm{hm}^{2}\right)$ of the region's total cultivated area is irrigated compared to $37 \%$ in Asia and $14 \%$ in Latin America $^{[9]}$. Thus Africa is far from achieving its irrigation potential, which is estimated at 42.5 million $\mathrm{hm}^{2}$. According to recent studies, the development of small-scale irrigation could expand irrigation by some 30 million hectares in SSA (a four-fold increase over the current area), generate annual net revenues of US\$22 billion, and improve food security and incomes for some 185 million people $e^{[10,11]}$. Therefore, scaling up the use of small-scale irrigation systems (with special emphasize on cheaper and sustainable access to energy) should rise to the top of African development priorities. With targeted investments and policies to 
expand small-scale irrigation, the problems of hunger, poverty and malnutrition can be addressed. The smallholder farmers in SSA have the potential to improve irrigation water management and increase their agricultural productivity if they are provided with the low cost irrigation delivery systems and water efficient irrigation technologies ${ }^{[11]}$. This requires identification, testing and dissemination of appropriate irrigation technologies to transition from existing low productive and uncertain rainfed production systems to a more reliable and productive irrigated agricultural systems. This transition can also help in protecting rangelands and forests from conversion to cropped agriculture ${ }^{[11,12]}$.

While some areas of Africa experience physical water scarcity, economic water scarcity limits greater development of available water resources for irrigated agriculture. The capital to develop irrigation infrastructure and the institutions to fund ongoing operations and maintenance do not warrant the production of 'cheap staples' without government support ${ }^{[13,14]}$. The irrigation opportunity is for intensification and diversification of agricultural production with two or more high-value crops per year to draw in labor from less profitable dryland agriculture, increase employment during the lean season and reduce poverty. Often the most profitable irrigated crops will not be stapled foodstuffs, so enhancing the productivity of smallholder irrigation often requires exporting non-staples from the locality in exchange for irrigators purchasing staple foods. Irrigation in SSA has had major difficulties providing an adequate return on investment, due to weak water governance institutions, weak market integration, and significant degradation and abandonment of irrigated lands ${ }^{[13]}$. In the most recent years, however, a number of African countries have been prioritizing efforts to tackle the dilemma and achieve food self-sufficiency. Decision-makers will need the facts on how much water is used in irrigation as related to the amount of food or fiber produced. In this paper, we reveal past trends in the irrigation industry within the SSA region highlighting on the way forward for food self-sufficiency.

\section{Food self-sufficiency}

Self-sufficiency ratio (SSR) is an indicator of a country's ability to fulfill its food demand from its own production and is determined by the two factors of production and consumption ${ }^{[15]}$. The concept of food self-sufficiency is generally taken to signify the level to which a country can satisfy its food needs from its own domestic production $^{[16]}$. In Figure 1, 100\% food self-sufficiency is represented by the diagonal line that indicates where food production is equal to food consumption. The diagram could be further refined by plotting individual countries within the sub region onto it to show where they fall relative to the $100 \%$ self-sufficiency line. Some countries would fall over the line, indicating that they are more than self-sufficient, and some countries would fall below it, indicating that they are in food deficit.

Although the percentage of the world's population living in food self-sufficient countries has not changed a great deal on a global scale in the 1965-2005 time period, certain regions and countries have seen important changes over time. Luan et al. ${ }^{[17]}$ analyzed the trend in the African self-sufficiency ratio from 1961 to 2007, incorporating GDP per capita over 52 countries using cereals and starchy roots as the main parameters. They found that Africa's SSR has declined from 1.0 in 1961 to 0.8 in 2007 . The Northern and Southern Africa regions also showed a decrease in $\mathrm{SSR}^{[17]}$. The figures shown by African countries over this period can be seen in Figure 2.

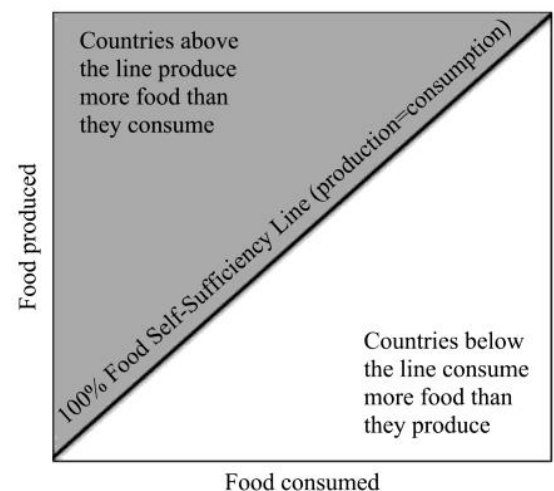

Figure 1 Basic representation of food self-sufficiency ${ }^{[4]}$

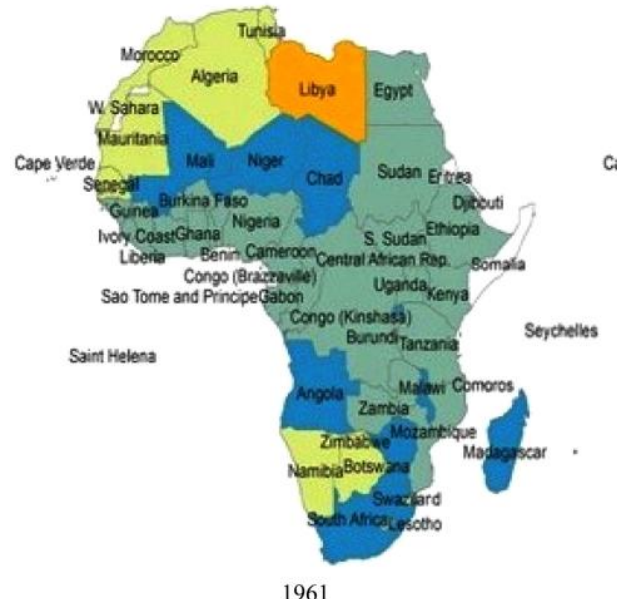

1961

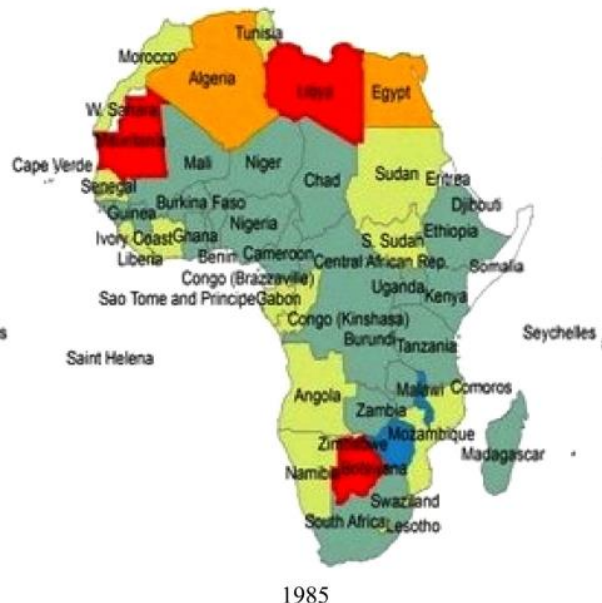

1985

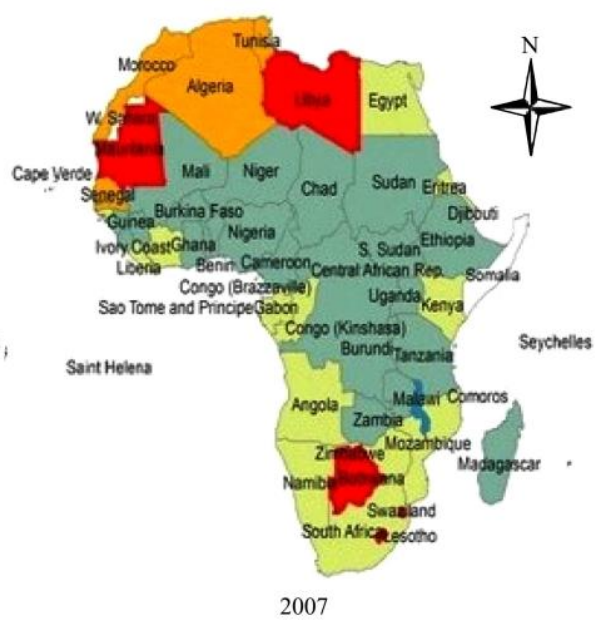

2007
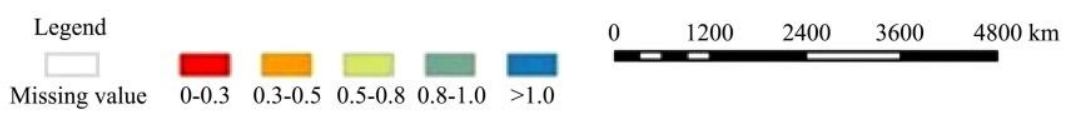

$\begin{array}{llllll}\text { Missing value } & 0-0.3 & 0.3-0.5 & 0.5-0.8 & 0.8-1.0 & >1.0\end{array}$

Figure 2 Changes in African countries' SSR over time (Adapted from Luan et al. ${ }^{[6]}$, based on FAO data)

Self-Sufficiency ratio (SSR) in Africa has been accompanied by both a strong critique and an uncomfortable reality. African food market growth and profitability are forecast to be concentrated in emerging local and regional African urban markets with demand expected to grow from $\$ 50$ billion to $\$ 150$ billion by the year 2030 . Larger domestic food markets are regarded as beneficial for 
widening food distribution coverage and enhancing food access with regional institutions seen to be paramount in facilitating channels to promote intra-regional trade. Other countries also experienced declines in their self-sufficiency. Japan, for example, saw its SSR fall from approximately $80 \%$ in caloric terms in 1960 to around $40 \%{ }^{[18]}$. Other countries have seen increases in their levels of food self-sufficiency over time. For example, Brazil, China and the Russian Federation and have seen an increase in their SSR since the $1980 \mathrm{~s}^{[19,20]}$. A number of countries are unable to increase their level of food self-sufficiency due to their natural resource endowments. Fader et al. ${ }^{[21]}$ concluded that approximately 66 countries are not able to be food self-sufficient due to natural resource constraints, including limited amounts of available cropland, water, and fertile soil. Imports have been important for these countries to meet their food needs. Indeed, international food trade has increased dramatically in recent decades. Many developing countries, particularly those in SSA, have increasingly had to rely on imports for their food consumption needs as shown by rising levels of food import dependence since the 1960s. This increase reflects declining levels of domestic food production as well as dietary shifts, demographic trends, and a changing ability to purchase food on global markets with export earnings ${ }^{[17,22]}$. At the same time that food trade has increased, there has been a growing reliance on certain exporting countries as sources of staple food imports. There are relatively few exporters of rice and wheat, for example, on world markets, with just a handful of key exporting countries for each crop. A number of SSA countries, for instance, rely on Thailand for nearly all of their rice imports, while other developing countries rely on France for nearly all of their wheat imports ${ }^{[20,23]}$. Some studies show that this concentration of sources of food imports can contribute to heightened fragility in the global food system, which may make it more vulnerable to instability due to both natural and economic disturbances $^{[23]}$.

\section{Water harvesting for irrigation}

Many authors have defined water harvesting and rainwater harvesting interchangeably, as the collection and storage of any form of water either from runoff or creek flow for irrigation use $^{[24-26]}$. Although the ancient practices were primarily designed to meet domestic water needs, gradually the technologies also came to be used for agricultural purposes. In recent decades, scientists in SSA, the Middle East and Southeast Asia have made efforts to develop and test a wide variety of techniques for collecting, storing, and using natural precipitation for agricultural purposes ${ }^{[27]}$. Agricultural uses include the supplemental irrigation of crops, the provision of water for livestock, fodder and tree production, and less frequently, water supply for fish and duck ponds. Recently, the concept has been extended to encompass in situ techniques and appropriate land management practices which enhance infiltration and reduce surface runoff and soil evaporation ${ }^{[28,29]}$.

In sub-Saharan Africa, almost 500 million people live in dry zones - deserts, grasslands and bush savannahs - in countries such as Mali, Niger and Zimbabwe. Another 245 million live in slightly wetter zones with forest savannahs, for example in large parts of Tanzania and Zambia, where run-off is still too low to irrigate fields. In any case, river water is needed mainly for urban, industrial and energy needs. Green water can be retained in three ways: collecting run-off; improving the infiltration of rain in soils; and managing land, water and crops across watersheds to increase water storage in soils, wetlands and the water table ${ }^{[30]}$.
Small-scale water harvesting methods include terracing to conserve soil moisture, as in the famous Fanya-juu terraces of Machakos, Kenya; or using dams and ditches to channel run-off into fields, as widely used in Eritrea and Israel. Storage systems such as ponds, tanks and sub-surface storage in sand and soil, used in places such as northern Mexico, Ethiopia, Sudan and India, offer another approach. Together these systems can hold the equivalent of a few rainy-season deluges, enough to bridge month-long dry spells. Water harvesting has been introduced to several parts of Africa, including Kenya and Tanzania since the 1980s by non-governmental and development organizations including the United Nations. It has improved the stability of crop yields and can raise productivity from $1 \mathrm{t} / \mathrm{hm}^{2}$ to $3-4 \mathrm{t} / \mathrm{hm}^{2[31]}$.

Green-water-management strategies need to span scales from fields to watersheds and river basins. Diverse sets of ecosystems should be protected to dampen the effects of flash floods and encourage underground flows to avoid erosion from run-off. Wetlands, meandering rivers, forests and patchy landscapes are natural capital assets that build resilience.

Watershed and river-basin management also protect local rainfall. Much tropical rain is convective - clouds produced from rising vapor over forests generate rain downwind. For instance, moisture from the West African rainforests in the south causes rain to fall on the semi-arid savannah in the north. Figure 3 shows the sub-Saharan water balance.

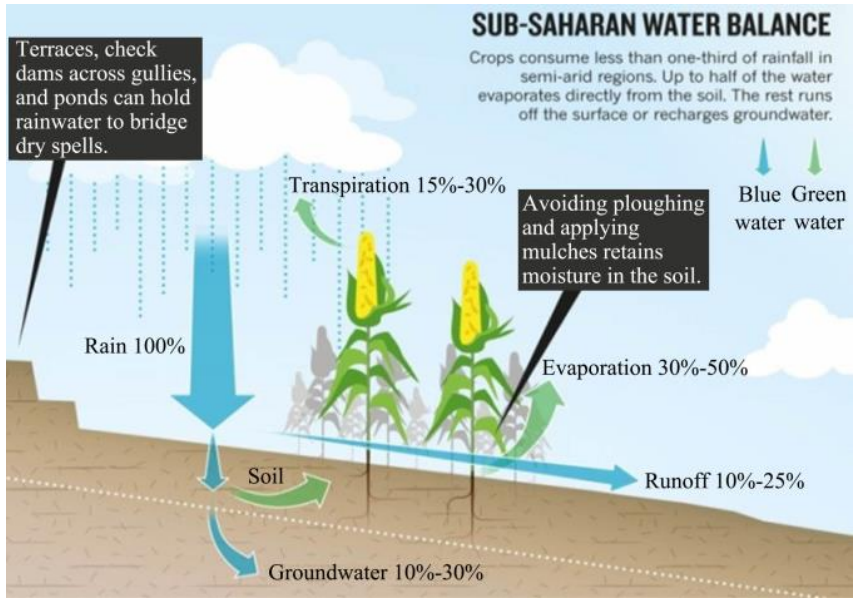

Figure 3 Sub-Saharan water balance ${ }^{[38]}$

Runoff may be harvested from roofs and ground surfaces as well as from intermittent or ephemeral watercourses. Rain water harvesting technology is used in SSA for collecting and storing rainwater from rooftops and the land surface or rock catchments. There are instances where the flood water has been harvested from all systems which collect discharges from watercourses. Rainwater is collected in simple vessels at the edge of the roof (Figure 4). Variations on this basic approach include the collection of rainwater in gutters, the amount and quality of rainwater collected depends on the area and type of roofing material. Reasonably pure rainwater can be collected from roofs constructed with galvanized corrugated iron, aluminium or asbestos cement sheets, tiles and slates. Thatched roofs tied with bamboo gutters, bamboo roofs are least suitable because of possible health hazards. Roofs with metallic paint or other coatings are not recommended as they may impart tastes or colors to the collected water. The groundwater available in urban localities and Metropolis may not cope up with the ever increasing demand and results in the over-exploitation of groundwater with inadequate replenishment due to urbanization. The rainwater runs off into the 
sea as the ground area available for percolation for recharging is meager/insignificant. Hence the rooftop rainwater harvesting method is best suitable for the conservation of rainwater and recharging the groundwater aquifer. Roof catchments should also be cleaned regularly to remove dust, leaves and bird droppings so as to maintain the quality of the water.

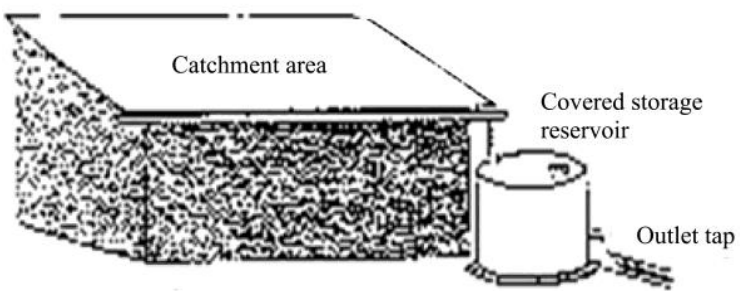

Figure 4 Rooftop catchment system

Land surface/ground catchments technique is a less complex way of collecting rainwater. It involves improving the runoff capacity of the land surface through various techniques, collection of runoff with drainpipes, etc. and storage of collected water (Figure 5).

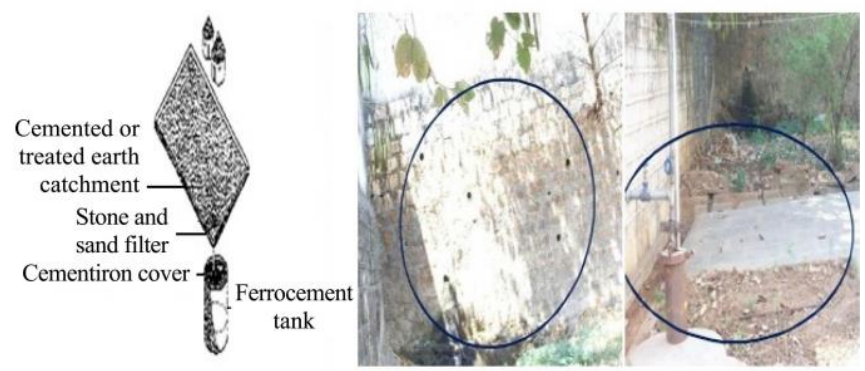

Figure 5 Ground catchment system

Storage reservoirs on the surface or underground may include earthen dams. This technique is ideally suited for areas where permeable sandy horizons within 3-5 m below ground level and continuous up to the water level under unconfined conditions, by which copious water available can be easily recharged. In this technique, 1-2 $\mathrm{m}$ wide and 2-3 $\mathrm{m}$ deep trench is excavated, the length of which depends on the site availability and volume of water to be handled. An injection well of $100-150 \mathrm{~mm}$ in diameter is constructed, piercing through the layers of impermeable horizons to the potential aquifer reaching about 3-5 m below water levels $(1-10 \mathrm{~m})$ from the bottom of the trenches. Depending upon the volume of water to be injected, the number of injection wells can be increased to enhance the recharging rate. This technique provides more opportunities for collecting water from a larger surface area. There is a possibility of high rates of water loss due to infiltration into the ground, is mainly suitable for storing water for agricultural purposes (marginal quality). Techniques for increasing runoff within ground catchment areas include:

1) Clearing/altering vegetation: This can induce more soil erosion. Use dense vegetation cover such as grass to maintain a high rate of runoff and minimize soil erosion.

2) Increasing slope: Use of plastic sheets, asphalt or tiles along with slope can further increase efficiency by reducing both infiltration losses and soil erosion. The rate of runoff has to be controlled to minimize soil erosion from the catchment field.

3) Soil compaction by physical means: It involves smoothing and compacting of soil surface using equipment such as graders and rollers. It helps to minimize soil erosion rates, conservation bench terraces are constructed along a slope perpendicular to runoff flow.
4) Soil compaction by chemical treatments: Soil treatments as sodium can significantly reduce the soil permeability. The use of aqueous solutions of a silicone-water repellent is another technique for enhancing soil compaction. Soil compaction can induce greater rates of soil erosion and may be expensive. The use of sodium-based chemicals may increase the salt content in the collected water, which may not be suitable both for drinking and irrigation purposes.

Conveyance systems are required to transfer the rainwater collected to the storage tanks. This is usually accomplished by making connections to one or more down-pipes connected to the rooftop gutters. When selecting a conveyance system consideration should be given to the fact that, when it first starts to rain, dirt and debris from the rooftop and gutters will be washed into the down-pipe. Thus, the relatively clean water will only be available sometime later in the storm. In order to safely fill a rainwater storage tank, it is necessary to make sure that excess water can overflow, and that blockages in the pipes or dirt in the water do not cause damage or contamination of the water supply. The design of the funnel system, with the drain-pipe being larger than the rainwater tank feed-pipe, helps to ensure that the water supply is protected by allowing excess water to bypass the storage tank.

Collection device/Storage tanks for collecting rainwater may be either above or below the ground. Precautions required in the use of storage tanks include the provision of an adequate enclosure to minimize contamination, and a tight cover to prevent algal growth and the breeding of mosquitoes. Open containers are not recommended for collecting water for drinking purposes. Rooftop rain water collected may be recharged to groundwater reservoir through:

1) Abandoned dug well

2) Abandoned/ running hand pump

3) Recharge shaft

4) Defunct bore well

5) Trench/ pit with injection well

A simple rooftop rainwater harvesting as practiced in some villages using split pipe or Bamboo directing the flow from rooftop to a small drum or plastic tank. If there is a group of houses, the owners can collectively lead the rainwater into a subsurface tank situated in a commonplace. Another simple method of storage is letting the rain water into the exiting well through a filter media consisting of the following.

Layer 1: Layer of sand - fine to medium (150-300 mm)

Layer 2: Layer of gravel (200 mm)

Layer 3: Layer of medium pebbles bed $(500 \mathrm{~mm})$

There are certain limitations in adopting storage methods, in places where the monsoon period is only 3-4 months as we require a large number of storage tanks of bigger dimensions, and preservation of water in the tanks for a longer period is also hazardous. Hence, we have to go in for the recharging method.

\section{Typology of irrigation in SSA}

Initially, irrigation in Africa was associated with irrigation plains of large perennial rivers, such as the Niger, Senegal, Nile, Volta, Zambezi, etc. where governments developed the first large irrigation schemes. Since the end of the 1980s, the irrigation sector has undergone important changes, such as the liberalization of the production chain, the transfer of scheme management to users, and the emergence of environmental concerns. 
Furthermore, donor interest in this sector has waned for a number of reasons, such as the decline in world food prices, the high per-hectare development cost (which moreover increases because the easiest areas to develop for irrigation have already been developed), investments necessary for rehabilitation, and environmental standards (which discourage the construction of dams). There is a tendency to promote small irrigation projects (sometimes with private-sector investment) and user participation on the basis of the better results obtained. At the same time, the use of pumps (powered by animals, humans or motors) has enabled groundwater use to become more widespread. This has given rise to a new environmental problem: the overexploitation of aquifers and its numerous consequences (seawater intrusion, sustainability, etc.). Other major environmental problems related to irrigation in SSA are (a) erosion and its consequences and silting up or sedimentation of water bodies, dams and canals; (b) proliferation of aquatic vegetation; and (c) the drying up or the risk of drying up of wetlands. Depending on the regions, irrigation is seen as a necessary technique without which agricultural production would be practically impossible, or as a means to increase productivity and cropping intensity, and to favor crop diversity; hence, the large variety of techniques developed for water management. Growing sub-Sahara African populations and economies will increase demand and competition for water. Allocating water to irrigation may have significant opportunity costs in the coming decades, especially in drylands where water is already scarce. For example in the Souss Massa basin, in Morocco, many farmers rely on water-intensive crops in a context of increasing demand from other water-using sectors and recurrent droughts. Perennial crops, such as citrus, are commercially valuable but they are also 'lock-in' demand for water as they take several years to mature. In SSA, agricultural production has increased slowly, and for a number of reasons the irrigation sector has not yet played a major role to cover the imbalance between food demand and supply to benefit farmers and generate jobs for the youth in particular. In general, donors and decision-makers are aware that SSA has significant land and water potential. Therefore, it is important to examine why investments in irrigation have been low in the last decades and understand where irrigation has performed well and why others continue to fail. This should enable policy makers to avoid mistakes involving investments in irrigation and to ensure that the benefits of irrigation are equitable and sustainable. Sub-Saharan Africa could irrigate 42.5 million $\mathrm{hm}^{2}$ based on available land and water resources. The greatest potential is in Mozambique, followed by Ethiopia, Nigeria, and Ghana. Countries such as Cameroon, Chad, Ethiopia, Mali, Niger, South Africa, Sudan, Tanzania, Togo, and Uganda each have at least $100000 \mathrm{hm}^{2}$ of land that could be irrigated ${ }^{[32]}$. It also has an average of $0.27 \mathrm{hm}^{2}$ of cultivated area per inhabitant in Africa ( 0.24 ha for average in the world) and 1.02 ha per economic active person engaged in agriculture ( 1.16 ha for the average in the world). These numbers should be compared and analyzed by taking into account the population growth and the economically active population engaged in agriculture. Population growth in Africa is relatively high ( $2.2 \%$ per year) when the average in the world is only $1.2 \%$ per year. It means that the pressure on agriculture and irrigation sector is higher in Africa today and in the future, to ensure food security and nutrition to more people. The same remark is valid if we consider that $56 \%$ of the economically active population is engaged in agriculture against $21 \%$ as an average in the world. It is also an opportunity for agricultural transformation if decisions on investments in irrigation are made wisely to optimize production and generate employment for the active agricultural population. In the early 1960s, there was 7.4 million ha of the irrigated area under cultivation in Africa $^{[33]}$. Although this area has nearly doubled to 13.6 million $\mathrm{hm}^{2}$ after almost 50 years, in 2006 African countries irrigated just $5.4 \%$ of their cultivated land, compared with a global average of around $20 \%$ and almost $40 \%$ in $\mathrm{Asia}^{[34]}$. Hence the irrigation sector's contribution to agricultural output is relatively small. Geographical coverage is also skewed since a large proportion of irrigated land is concentrated in five countries, namely South Africa, Egypt, Madagascar, Morocco and Sudan ${ }^{[35]}$.

The major livelihood zones in SSA related to production and water as a limiting and potential factor for irrigation development are mainly: agro-pastoral zones, cereals in all SSA zones (wheat, barley, maize, millet, rice and sorghum), root crops, tree crops and commercial crops (e.g. cotton in Egypt, Sudan and Senegal and sugar cane in Senegal, Egypt and South Africa). Currently, production of the above crops is mainly rainfed and although production on irrigated land is expanding, it still insufficient to eradicate hunger, to secure food and improve nutrition. Indeed, SSA is making progress but still experiencing the worst nutrition situation $^{[36]}$. This situation of vulnerability has continued despite the declined prevalence of undernourishment in sub-Saharan Africa in terms of percentage (from 33\% to 23\% between 1990-1992 and 2014-2015 ${ }^{[36]}$ but increased undernourishment in terms of people (229 million in 2014 compared to 175.7 million in 1990). Demand for food is increasing in volume due mainly to population growth. Figure 6 shows the positive trend on increased food and feed consumption per capita in SSA and an increase in the volume of demand for food resulting from high population growth (Africa's population is expected to more than double, rising from 1.1 billion today to at least 2.4 billion by 2050 . Nearly all of that growth will be in the 51 countries of sub-Saharan Africa ${ }^{[37]}$. It calls for more agricultural production per capita per year by 2025 to mitigate the imbalance between agricultural production and demand, and expansion of the agricultural land under irrigation will be an important way to meet this challenge.

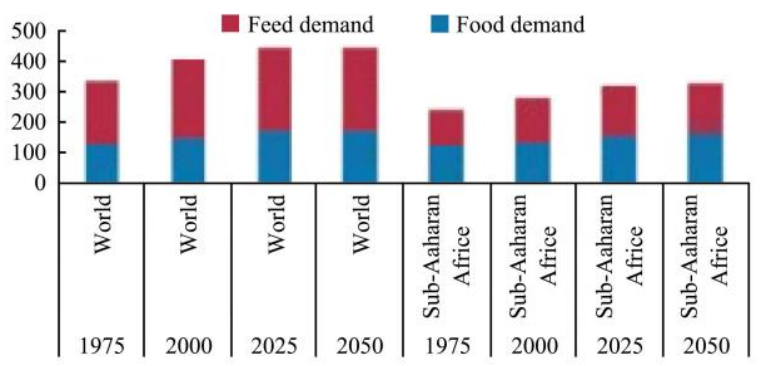

Figure 6 Food and feed consumption in sub-Saharan Africa Food vs. feed Consumption in the World vs. sub-Saharan Africa $(\mathrm{kg} / \text { person/year })^{[38]}$

Considering its arable land and water resources, Africa has a lot of potentials to transform its agriculture and raising productivity is a major factor to achieve this objective. Physically, improvement of productivity in rainfed and irrigated areas require the availability of a technological package at farm level (e.g. fertilizers, water on time according to climate conditions and crop growth stages, made possible by irrigation). The fact is that average cereals yield is almost five times higher in South Asia than sub-Saharan Africa (Figure 7) and the yield growth in Africa for the last fifty years is really slow if not stagnant. The productivity 
of most crops is low in Africa, which is an issue today but an opportunity for a large improvement for the future.

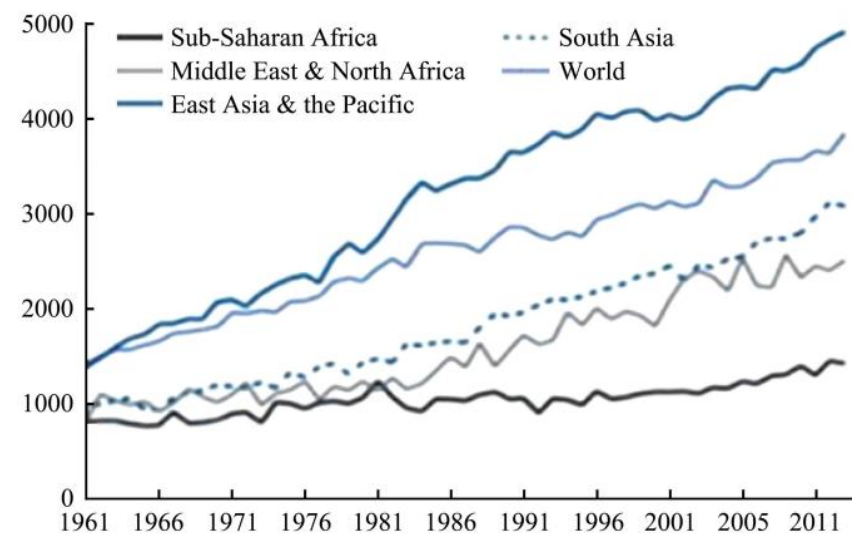

Figure 7 Cereal yields $\left(\mathrm{kg} / \mathrm{hm}^{2}\right)$ by region, 1961-2011

\section{Emerging irrigation technologies in SSA}

Since the 1950s, the total irrigated area in the world expanded rapidly. Between 1961 and 1990, the area under irrigation increased by almost 100 million $\mathrm{hm}^{2}$. The annual growth rate of irrigated areas exceeded $2 \%$ during the 1960s and 1970s. Currently, the growth rate worldwide has slowed down to a moderate 0.8\%. Between 1961 and 1990, the irrigated area in Asia expanded by 70 million $\mathrm{hm}^{2}$ (FAO, 1992). Within the context of national agricultural and water policies, that reflect a wide range of economic, political and environmental considerations and stakeholder interests, many irrigation schemes worldwide suffer from poor management, both in its technical and social dimensions. This often leads to unsustainable practices with decaying infrastructure and a reluctance of users to contribute to their maintenance. Many irrigation schemes are caught in downward cycles of poor maintenance, poor water delivery performance and dwindling agricultural productivity and profits. The traditional agricultural systems based on the cultivation of crops, mainly for home consumption, have to be transformed into a more diversified system with higher agricultural inputs and to be market oriented.

The irrigation system typologies observed in sub-Saharan Africa, especially Ghana and Liberia may be broadly classified into two groups based on their current level of formalization. These are (1) the conventional systems, which are mainly initiated and developed by the Government or various non-governmental organizations (NGOs); and (2) the emerging systems. Ghana's irrigation systems may be classified into four major typologies based on such criteria as ownership/management, source of water, type of infrastructure or technology involved, and source of power for abstracting, conveying, and distributing water ${ }^{[39,40]}$. These include public systems; small reservoirs and dugouts; river/lake lift private systems; and groundwater systems. These four typologies can be subdivided: public-owned surface irrigation systems; public-private partnership commercial systems; small reservoirand dugout-based systems; private- or group-based river-lift systems; groundwater-based irrigation systems; and lowland/inland valley rice water capture systems.

Pressurized water application methods (micro and sprinkler irrigation) are considered as the leading water-saving technologies in irrigated agriculture. At present, of the total world irrigated area, about $15 \%$ (444 million $\mathrm{hm}^{2}$ ) is equipped with pressurized methods, comprising micro-irrigation $\left(9\right.$ million $\left.\mathrm{hm}^{2}\right)$ and sprinkler irrigation (35 million ha), most of which are located in America and Europe. A vast range of micro and sprinkler irrigation systems could be designed to suit to small and large farm sizes, soil and crop types. Improved surface irrigation methods like level furrows, dead level basins also provide high application efficiency. However, there are three principal categories of irrigation that are recognized in sub-Saharan Africa:

\subsection{Informal/smallholder Irrigation}

Informal/smallholder irrigation (Figure 8) is practiced by individuals who cultivate an area of up to about $0.5 \mathrm{hm}^{2}$ or more by using simple infrastructure for water storage, conveyance and distribution. This form of irrigation is characterized by the relatively small investment by farmers, dominated by manual fetching of water with buckets or watering cans with few lifting water by pumping.

Traditional and community initiated schemes fall under this category which comprises irrigators in the south-eastern coastline, groundwater irrigation, irrigators in inland valley and along with dams and dugouts as well as irrigated urban and peri-urban agriculture. Presently, it is estimated that informal smallholder irrigation covers an area of $189000 \mathrm{hm}^{2}$ in Ghana.

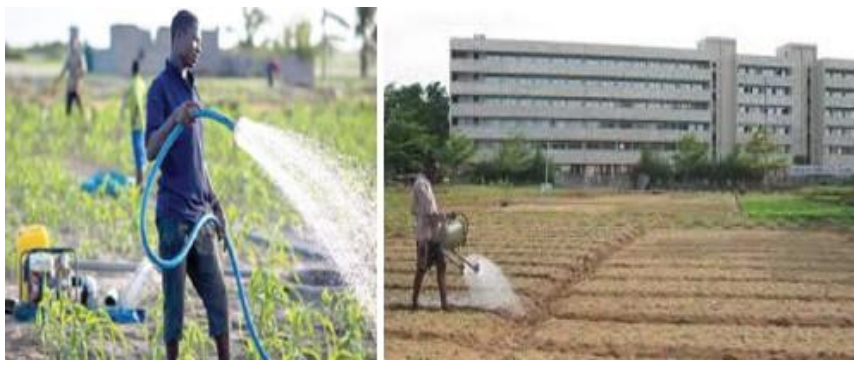

Figure 8 Informal/smallholder irrigation

\subsection{Formal Irrigation}

Formal irrigation (Figure 9) is the type that depends on some form of permanent irrigation infrastructure funded by the state alone or together with development partners and civil society organizations. The development of formal irrigation schemes in Ghana dates back to the 1960s. Ghana Irrigation Development Authority (GIDA) presently has 57 formal irrigation schemes covering about $12000 \mathrm{hm}^{2}$. On many schemes, the rates of utilization are low due to poor operation and maintenance of the facilities and high energy tariffs. Specifically, the rate of utilization of pump schemes is $46 \%$ while that of gravity schemes is $134 \%$ both of which fall below $200 \%$ mark for irrigation schemes.

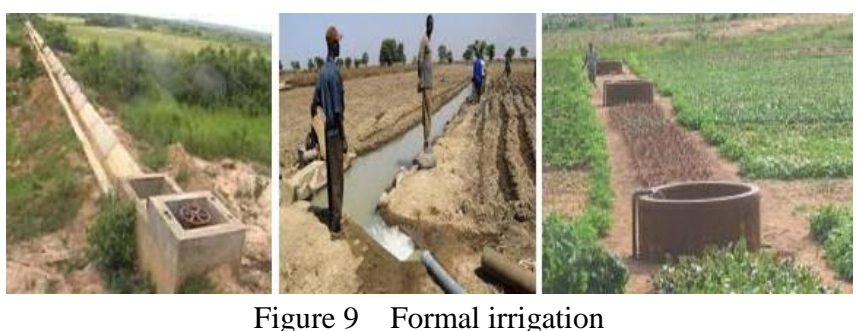

\subsection{Large Scale Commercial Irrigation}

Large scale commercial irrigation (Figure 10) which falls under either formal or informal irrigation, is usually export-driven and involves the cultivation of high value fruits and vegetables. Large scale commercial irrigation is formal when the government provides infrastructure such as headworks, conveyance and primary water distribution facilities while the private investor provides secondary water distribution and application machinery and 
equipment. There are an estimated $21000 \mathrm{hm}^{2}$ of large scale commercial irrigation in Ghana currently.

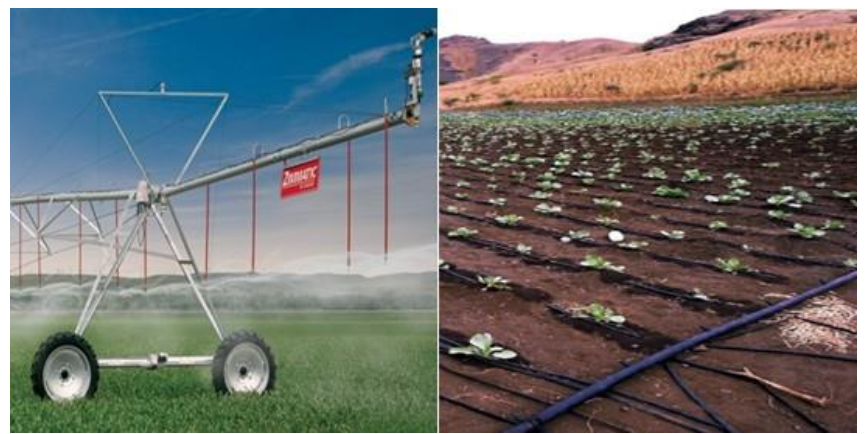

Figure 10 Large Scale commercial Irrigation practiced in some regions

Irrigation offers benefits including yield security during dry seasons and times of drought, economic opportunity by increasing yields, choice of high value market driven crops, multiple cropping seasons annually, out of season production, and protected agriculture. Irrigation is additionally beneficial to nutrient management and can promote food/nutrition security and crop quality. That said, irrigation is not without its disadvantages. Irrigation can confound water scarcity (depletion of water supplies), compete with other water consuming sectors, and raise environmental concerns including pollution, soil salinity and water logging. Irrigation comes only with an economic cost, as equipment, labor, maintenance, water, energy all require investment. Irrigation technologies and operation can be separated into gravity fed - surface (flood and furrow) and pressurized (sprinkler and drip) systems. Components of gravity fed systems are water source and storage, pump (if necessary), and channels or pipes to distribute water to the field. Challenges in surface irrigation include minimizing losses throughout the system and insuring delivery is as uniform as possible. Scheduling of surface irrigation is, at worst, whenever there is water, however much there is, and, at best, based on combined data regarding the soil, crop, and weather. Scheduling for surface irrigation attempts to apply the maximum water per irrigation event and a minimum number of events. Sprinkler irrigation requires water under pressure and delivery to the field via pipes and emitters and can be either stationary or moving. The design of a sprinkler system relies on knowledge regarding pressure-flow relationships in laterals between sprinklers and in the emitters themselves. The basic concept and challenge in sprinkling are to uniformly apply water to a field. Scheduling of sprinkler irrigation is similar to that of flood; return of plant available water in the soil each event. Drip irrigation presents a paradigm shift in how we provide water to crops, most importantly due to partial wetting of the soil, providing just plant water needs, enabling very high irrigation frequency and maintenance of relatively high water content in the root zone, and allowing precise nutrient (fertilizer) management together with water management. Drip irrigation systems include water under pressure, an "irrigation head" with filtration, automation, and fertigation, mains and laterals to deliver to the field and emitters to release water at desired and constant flow rates. Drip systems must be maintained, mostly to prevent clogging. Technology for smallholder drip irrigation will necessarily be site-system-situation specific and will involve appropriate technology and maintenance. Some $65 \%$ of water used for agriculture is estimated to not be utilized by plants. Water use efficiency and water saving considerations in irrigated agriculture require proper design and management of water storage and distribution systems to avoid losses and in smart irrigation scheduling. Irrigation technology can be beneficial only in context with the network of institutions, policies and practices that enact it. Technology can, and already does, aid agriculture in innumerable ways. One prominent part of agriculture that can use technological innovation to increase efficiency and effectiveness is irrigation. The adoption of modern farming techniques in traditional agriculture could be an alternative solution to deal with the increasing food security in SSA. The modern techniques involve much higher use of advanced technology and automation for land-use optimization. An aeroponic system is one of the revolutionary and more sustainable methods of a soilless system as it lowers the requirement of water and saves considerable space and soil $^{[41]}$.

With the acceleration of land circulation in SSA and the strong demand for large-scale planting, combined with the current shortage of rural labor, water scarcity and soil ecological deterioration, traditional agricultural production methods need to be changed. Modern agricultural science and technology should be used to promote agriculture in an industrialized way. Water and fertilizer integrated irrigation equipment based on sprinkler irrigation and drip irrigation technology are becoming very common in several parts of the world especially in China. According to soil moisture, crop fertilizer requirements and characteristics, the appropriate proportion of fertilizer and irrigation water will be exchanged. Together, the fertilizer is sprayed evenly, regularly, and quantitatively in the crop growing area. In the process of water and fertilizer supply, the most effective way of supply is how to realize the simultaneous supply of water and fertilizer, give full play to the interaction between the two, and provide the water to the crops while exerting the role of fertilizers to achieve the simultaneous supply of water and fertilizer.

Modern technologies undoubtedly have the potential to raise the productivity of water and labor. Technically, they are best suited to conditions where water is scarce and the opportunity costs of labor are high. Modern technologies have yet to be seriously tested and evaluated in the region. There is also a concern for their introduction into developing countries to be driven more by commercial interests rather than need. This can lead to inappropriate use. Precision agriculture, satellite farming or site specific crop management is a farming management concept based on observing, measuring and responding to inter and intra-field variability in crops. The goal of precision agriculture research is to define a decision support system for whole farm management with the goal of optimizing returns on inputs while preserving resources $^{[42-44]}$.

Smart irrigation control systems (Figure 11) typically include either a stand-alone controller or an add-on device that interfaces with a conventional clock-type controller. The weather-soil moisture-based technologies incorporated into these devices allow them to function similar to a thermostat. Like a thermostat, the devices permit irrigation to occur when needed rather than on a preset schedule. Regardless of the specific method or technology, the concept is for the appropriate irrigation quantity to be applied at the appropriate time. With the rising demands on water resources, the use of reclaimed water for irrigation has gained considerable interest in many parts of the region. Irrigation controllers that incorporate soil moisture sensors for feedback control can have improved performance, but there has been concern about using 
these moisture sensors with reclaimed water, which can affect the soil dielectric permittivity and thus affect the soil moisture sensor values.

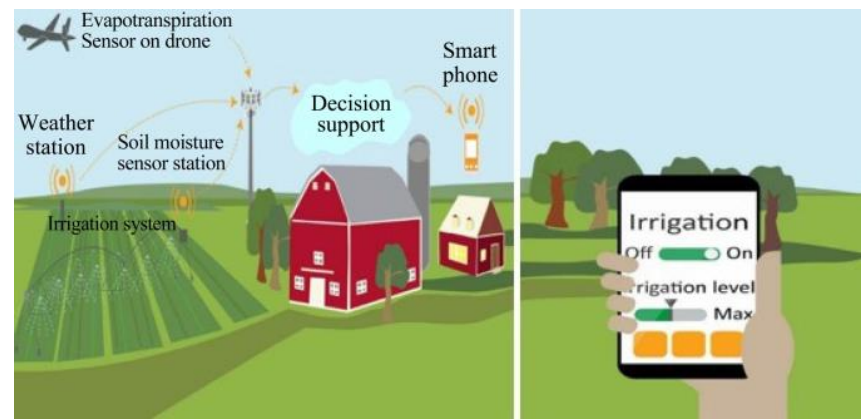

Figure 11 Smartphone-integrated precision agriculture system

\section{Forward way in dealing with the irrigation challenge in SSA to meet food self-sufficiency}

One of the key factors contributing to agricultural productivity growth in the green revolution in India was public investment in irrigation $^{[45]}$. Irrigation has spatial and temporal productivity benefits. It allows agricultural production on drylands, which cover three-quarters of the agricultural land area in sub-Saharan Africa ${ }^{[46]}$. Rainfed agriculture in drylands is either unfeasible or extremely risky, and irrigation makes it possible to produce crops and reduce production risks ${ }^{[47]}$. Additionally, irrigation allows dry season production, expanding the period of availability of vegetables and other crops. Irrigated crops are healthier and of better quality, especially in drylands. Returns to irrigation are high. Irrigation in drylands increases yields by an estimated $91 \%$ and total factor productivity by about $3 \%{ }^{[48]}$. Figure 12 represents the share of cultivated area in SSA that is equipped for irrigation against other areas within the African community.

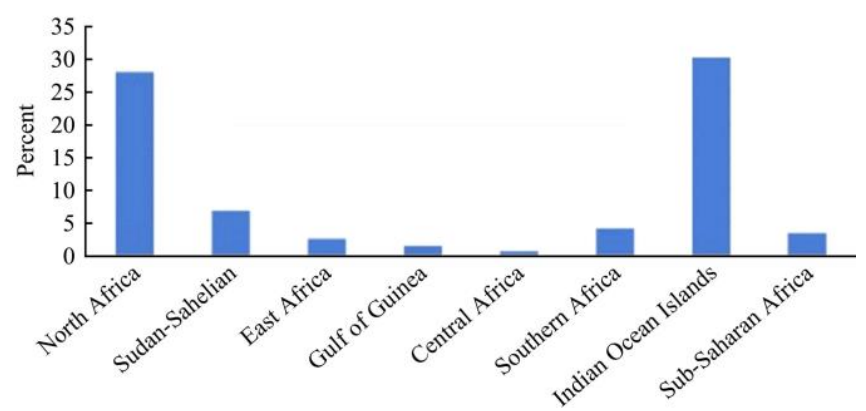

Figure 12 Share of cultivated area in SSA that is equipped for irrigation $^{[49]}$

In the face of adverse impacts of climate change on agricultural systems, including increased incidence of pests and diseases, Africa's food security situation will be under threat. Its agriculture needs to adapt rapidly by building capacity for observations at regional, national and local levels to better understand factors informing shifts in pest and disease regimes. Options to overcoming productivity-related challenges can continue to be learned from the experiences of countries with successful irrigation systems. Governments are in charge of heavy collective water infrastructures (water storage, hydraulic networks, and pumping stations) and heavy maintenance to facilitate access to water. At small scale levels for example in Morocco, a special agency is created for advisory and extension in agriculture and in particular in irrigation, focusing on productivity. The private sector is involved and private technical advisors are trained and subsidized for providing advisory and extension services across irrigated areas in the country. In North Africa, in addition to the commitment of the Governments to heavy investments, modern irrigation equipment (drip and sprinkler) are subsidized at the farm level and for the first installation, between $60 \%$ and $100 \%$ of their cost, in particular for smallholders. Financial and technical empowerment of farmers is a challenge and condition to improve productivity at the farm and consequently at the national level, achieving agricultural transformation objective from bottom to top (i.e. for large and small farmers), through improving productivity, ownership of operation and maintenance and cost recovery of irrigation investments and services. Investing in full irrigation or water harvesting, upgrading rain-fed areas and managing supplementary or deficit irrigation can multiply productivity in drought-prone regions. Deficit irrigation could necessarily be an appropriate yield optimization and water saving technique for crops such as cotton in desert environment ${ }^{[50]}$. The most advantage can be gained by incorporating rain-fed areas in a program of productivity improvement through supplementary irrigation, which is a lower cost than fully irrigated areas and also improves equity. Indeed, investment in agricultural water management in rainfed areas may focus on a large number of farmers, a bigger cumulative surface and can achieve big production increase in terms of volume with acceptable productivity.

Small irrigation systems promise both social and economic benefits because of the prevalence of small farms. Smaller scale irrigation projects are more viable options for increasing agricultural productivity among smallholder farmers, but management challenges need to be overcome. Ethiopia has established a program for small-scale irrigation under the Agency for Agricultural Transformation with the objective of promoting the efficient use of improved irrigation. Publicly managed rural infrastructure faces many challenges that help to account for the slow development of irrigation potential. Local water user associations suffer from low capacity to manage small-scale irrigation systems. Most irrigation infrastructure is large scale and dam-based or small scale and based on groundwater, small reservoirs, river diversion, or water harvesting. Because big dams are expensive to build and maintain, and complex to operate and manage, they are no longer being built for a single purpose; irrigation is just one objective among others. One approach to reducing fixed costs and enhancing the quality and responsiveness of irrigation operations and maintenance has been to transfer public sector responsibility for operating and managing irrigation works to water user associations, which act as intermediaries between farmers and the state owners of irrigation infrastructure. An example is the Nakhlet Small-Scale Irrigation Scheme on the northern bank of the Senegal River in Mauritania, which irrigates $27.5 \mathrm{hm}^{2}$ of land. Nearly 30 farmers cultivate 119 fields and realize an average rice yield of $5.5 \mathrm{t} / \mathrm{hm}^{2}$ compared with an average of 5 tons per hectare countrywide ${ }^{[51]}$. To work, such schemes require land tenure reform (to incentivize long-term investments and enable the land to be used for collateral), efficient and responsive management of infrastructure by trained water user associations, adequate inputs and markets, and access to affordable credit. The type of irrigation system that is most suitable depends on the area's agro-ecological conditions and government budget constraints. Large-scale irrigation systems serve multiple purposes beyond the agricultural sector, whereas small-scale 
irrigation schemes are less expensive to build and can yield results more quickly. An important consideration is the internal rate of return, which is high for irrigation projects in sub-Saharan Africa. Other considerations in deciding between large-scale and small-scale irrigation systems include potential productivity gains, economic costs and benefits, and poverty reduction and equity impacts and environmental impacts

Table 1 Investment cost and average economic internal rate of return for large-scale and small-scale irrigation investment in sub-Saharan Africa ${ }^{[49]}$

\begin{tabular}{lccccc}
\hline & \multicolumn{2}{c}{ Large-scale irrigation } & & \multicolumn{2}{c}{ Small-scale irrigation } \\
\cline { 1 - 3 } \cline { 5 - 6 } Sub-region & $\begin{array}{c}\text { Investment } \\
\text { cost } \\
\text { /USD·hm }\end{array}$ & $\begin{array}{c}\text { Average } \\
\text { internal rate } \\
\text { of return/\% }\end{array}$ & $\begin{array}{c}\text { Investment } \\
\text { cost } \\
\text { /USD·hm }\end{array}$ & $\begin{array}{c}\text { Average } \\
\text { internal rate } \\
\text { of return } \%\end{array}$ \\
\hline Sudano-Sahelian & 508 & 14 & & 4391 & 33 \\
Eastern & 482 & 18 & & 3873 & 28 \\
Gulf of Guinea & 1188 & 18 & & 8233 & 22 \\
Central & 4 & 12 & & 881 & 29 \\
Southern & 458 & 16 & & 413 & 13 \\
Total & 2640 & 17 & 17790 & 26 \\
\hline
\end{tabular}

Financial analyses show that the rates of return for farmers to invest in some soil-conserving technologies, in marginal dry areas, are often not high enough to trigger technology adoption. Development investments are necessary to provide farmers with incentives to stimulate adoption. Such incentives can be justified because the economic rate of return to investment is satisfactory if these costs are accounted for. In addition, there are important environmental benefits- in the form of reducing soil erosion, maintaining soil fertility, and conserving soil moisture - that can be generated from public investments in dry areas. Successful, sustainable natural resources management requires approaches that go beyond the conventional and biophysical aspects and that capture the holistic nature of the problem by integrating economic, environmental and social aspects ${ }^{[52]}$. Land tenure, for example, is an important factor affecting the adoption of soil-conserving technologies. The long-term environmental benefits of conservation cropping may be irrelevant to farmers whose planning horizon is limited by insecure land tenure. Regardless of the high rates of return to investments in agricultural research and development, growth in public spending for food and agriculture has slowed down substantially. In developing countries, irrigation infrastructure investment is mostly funded by the public sector. Increasing investment and involvement of the private sector is crucial for the up-scaling of irrigation technologies. Irrigation investment strategies should include measures for the adoption of water saving irrigation technologies.

Risk is a critical factor influencing adoption and thus it needs explicit attention in the diagnosis and intervention measures ${ }^{[33]}$. New technologies may improve yield and product quality, but may not necessarily improve input use efficiency. For example, the introduction of supplemental irrigation into traditionally rainfed agriculture has increased yields and reduced yield variability. However, the benefits will be fully realized only when farmers have adequate technical know-how about the technology. Without this, water savings may be far less than what can be achieved.

The irrigation method is the most important variable in explaining the variation in efficiency in both technical and irrigation water efficiencies. A shift from traditional surface irrigation to modern irrigation methods, particularly sprinklers, leads to higher output oriented technical efficiency and irrigation water technical efficiency. However, even among farmers who use modern irrigation methods, there is still about $25 \%$ of water use inefficiency that can be eliminated by building farmer knowledge. Hence the need for extension interventions - with strong policy supports - to enable farmers to make the best use of new technologies. Participatory, community-led approaches are critical, particularly for land and water management technologies ${ }^{[54]}$.

Research findings are available on many of the key issues, although important knowledge gaps still exist. Examples include farm size, water allocation and costs, cropping patterns, inputs, and crop pricing. Water allocation among crops, techniques and growing seasons should consider the level of efficiency which may be attained under each option. Well designed, implemented policies are the key to the efficient use of scarce resources, growth in farm income and protection of the environment. Zhu et al. ${ }^{[55]}$ conducted a research that provided a holistic solution for constructing modern agriculture. The research content covered seven agricultural engineering fields, including farmland, mechanization, protected-area, processing and storage of products, logistics, environmental protection and agricultural information, which comprise the key technologies in the entire industrial chain of production before, during and after. Results from their study provided a roadmap of technical standards and construction programs for agricultural engineering in various typical regions, industries and operators' subjects, which constitutes a comprehensive and systematic solution for agricultural engineering technology in the blending of agricultural machinery and agronomy, the promotion of good farmlands, good seeds and manners, as well as the coordination of production, living and ecology during an adjustment in agricultural production.

Weak knowledge of groundwater resources potential, its use and the way to develop them pose challenges. Countries within the sub region therefore need to develop deep studies on the location and the potential of groundwater resources and in order to sustain the use of these resources, policy and legal rules have to be developed at the national level and for each aquifer. Yang et al. ${ }^{[56]}$ outlined three suggestions for managing water resources in the Manas River Basin. They emphasized practices that can increase the supply of surface water and reduce demand on groundwater which will eventually reduce groundwater depletion and increase sustainability. They also mentioned that there is a limit to the efficiency of irrigation systems due to the potential for soil salinization; thus, where possible, irrigated crops should be converted to rainfed crops to reduce groundwater depletion. Appropriate national guidelines and regulations for treatment and reuse of wastewater for irrigation need to be developed and implemented. Furthermore, temporal disconnects between water supply and demand should be managed through conjunctive use of surface water and groundwater and the provision of increased water storage. National and Sub-regional Capacity building programs should be organized focusing on irrigation institutions (public and non-public) to enable policy implementation to create or reorient at a sub-regional level a center of irrigation experiments and equipment certification, linked to research and experimentation institutions. Irrigating Africa is a core policy objective of a great many multilateral organizations, donors and national governments, in the expectation that this will reduce poverty, increase food security and promote economic growth and development. 
Community and institutional organization and support are necessary for its success. Community management includes both aspects of equity and sustainability and is challenged to support the development of simple, accessible, affordable but scientific and data-knowledge based methods and systems for irrigation delivery and scheduling. Community/societal contributions and responsibility are important in both the micro and macro scales. At the micro-scale, this can mean responsibility for water storage and allocation, energy supply, availability of appropriate (location, system, time, crop) technologies, investment, equipment purchase, maintenance, fertilizer purchase, extension - knowledge transfer, and accessibility to markets and marketing. On the macro scale, the community/society must enable investment, maintenance, market driven decision-making and management, and other support including access to knowledge and data. While irrigation and irrigation technologies appear to present opportunities for smallholder agricultural development, economic advancement and poverty alleviation, technology should not and cannot be separated from systems and policies. Appropriate technology for irrigation will always be site and system (crop, economic, social, and institutional) specific. Sustainable development of agriculture will be a result of system changes and adjustments.

\section{Conclusions}

Most sub-Saharan African countries have been unable to embrace food self-sufficiency although agricultural revolution is within reach. Provided the region can focus on supporting small-scale farmers to help meet national and regional demand for food, then the future looks very bright. Activities involved in irrigated agriculture should fit well in farming systems and be attractive and easily managed by farmers themselves. Our study concludes that many irrigation projects miss basic, yet vital, ingredients for success. These include enough finance for routine maintenance and reliable water supplies, among other factors. On the other hand, technically and financially successful commercial projects can be captured by elite interests and may deprive local communities and pastoralists of traditional land and water resources, undermining their livelihoods. If irrigation is to boost food production and reduce poverty in sub-Sahara Africa, lesson-learning is needed. There must be more efficient water use by developing local capacity and access to appropriate tools to understand the value of accurate soil moisture monitoring and measurement to reduce leaching of nutrients and salinization and increase the overall water-use efficiency of production systems and developing the skills of agricultural extension officers to backstop the learning process of farmers. Technologies alone will not achieve water savings unless supported through innovative management, policy and institutional reforms. Modernization of irrigation systems should not only be restricted to upgrading of physical infrastructure but also integrate improved irrigation services. Water saving measures need to be based on a thorough understanding of water balance and linkages between surface and groundwater and beneficial and non-beneficial uses of water. Irrigation investment strategies should include measures for the adoption of water saving irrigation technologies. Appropriate national guidelines and regulations for treatment and reuse of wastewater for irrigation need to be developed and implemented. There should be a road map for water supply strategy as a part of national development plans, including in particular multi-purposes big water infrastructures for inter-annual management; at inland and trans-boundary levels as well as the creation, rehabilitation and modernization of irrigation systems for both large scale and small scale. Sustainability should be the main orientation.

\section{Acknowledgements}

The National key research and development program No.2016 YFC0400202, the key teacher training project of Jiangsu Universit $\mathrm{y}$ and the Priority Academic Program Development of Jiangsu Hig her Education Institutions (PAPD).

\section{[References]}

[1] Godfray H C J, Crute I R, Haddad L, Lawrence D, Muir J F, Nisbett N, et al. The future of the global food system. Philosophical Transactions of the Royal Society B-Biological Sciences, 2010; 365(1554): 2769-2777.

[2] Spielman D J, Hartwich F, Grebmer K. Public-private partnerships and developing-country agriculture: evidence from the International Agricultural Research System. Public Administration and Development, 2010; 30(4): 261-276.

[3] Food and Agriculture Organization of the United Nations. Global hunger declining, but still unacceptably high. 2011. Available online: http://www.fao.org/hunger/hunger-home/en/ Accessed on [2017-08-13]

[4] Al-Gaadi K A, Hassaballa A A, Tola E, Kayad A G, Madugundu R, Assiri $\mathrm{F}$, et al. Impacts of center pivot irrigation system uniformity on growth of potato crop and residual soil nitrogen. Int J Agric \& Biol Eng, 2019; 12(1): 126-131.

[5] Suporn P, Pimwadee C, and Navaporn S. Applications of Smartphone-Based Sensors in Agriculture: A Systematic Review of Research, Journal of Sensors, 2015. DOI: 10.1155/2015/195308

[6] World Bank. Poverty in a rising Africa: overview. Washington, D.C. World Bank Group, 2015. http://documents.worldbank.org/curated/en/ 2015/10/25158121/poverty-rising-africa-overview.

[7] Svendsen M, Ewing M, Msangi S. Measuring irrigation performance in Africa. IFPRI Discussion Paper, International Food Policy Research Institute, 2009.

[8] Tafesse M. Small-scale irrigation for food security in sub-Saharan Africa. Summary Report and Recommendations of a CTA Study Visit. Ethiopia, January 20-29, 2003. CTA Working Document No. 8031. Wageningen: Technical Centre for Agricultural and Rural Cooperation.

[9] Amjath-Babu T, Timothy K, Sreejith A, Muhammad A, Harald K. Climate change and indicators of probable shifts in the consumption portfolios of dryland farmers in Sub-Saharan Africa: Implications for policy. Ecological Indicators, 2016; 67: 830-838.

[10] IFPRI. Increasing Agricultural Productivity and Enhancing Food Security in Africa. International Food Policy Research Institute, Washington, D.C., 2012.

[11] Morardet S, Merrey D J, Seshoka J, Sally H. Improving irrigation project planning and implementation processes in sub-Saharan Africa: diagnosis and recommendations. IWMI, Colombo, 2005; 87p. Available at http://www.iwmi.cgiar.org/africanwaterinvestment/ index.asp.

[12] Vanlauwe B, Coyne D, Gockowski J, Hauser S, Huising J, Masso C, et al. Sustainable intensification and the African smallholder farmer. Curr. Opin. Environ. Sustainability, 2014; 8: 15-22.

[13] Stirzaker R, Pittock J. The case for a new irrigation research agenda for sub-Saharan Africa. In J. Pittock, R. Q. Grafton, \& C. White (Eds.) Water, food and agricultural sustainability in Southern Africa, Prahran: Tilde University Press, 2014; pp. 91-107.

[14] You L, Ringler C, Wood-Sichra U, Robertson R, Wood S, Zhu T, et al. What is the irrigation potential for Africa? A combined biophysical and socioeconomic approach. Food Policy, 2011; 36: 770-782. doi: 10.1016/j.foodpol.2011.09.001

[15] Clapp J. Food Self-Sufficiency and International Trade: A False Dichotomy? State of Agricultural Commodity Markets - In Depth FAO, Rome, 2015. Available online: http://www.fao.org/3/a-i5222e.pdf. Accessed on [2018-01-26]

[16] Food and Agriculture Organization of the United Nations. Implications of Economic Policy for Food Security: A Training Manual, 1999. 
Available online: http://www.fao.org/docrep/004/x3936e/x3936e03.htm Accessed on [2017-11-26]

[17] Luan Y, Cui X, Ferrat M. Historical trends of food self-sufficiency in Africa. Food Security, 2013; 5(3): 393-405

[18] Kako T. Sharp decline in the food self-sufficiency ratio in Japan and its future prospects. Paper presented at the International Association of Agricultural Economists Conference. Beijing, China. August 2009. Available online: http://ageconsearch.umn.edu/bitstream/51570/2/kako\% 20Sharp\%20decline\%20in\%20food\%20self-sufficiency1.pdf Accessed on [2017-07-15]

[19] Porkka M, Kummu M, Siebert S, Varis O. From food insufficiency towards trade dependency: a historical analysis of global food availability. PLoS ONE.2013; 8(12): e82714.

[20] Puma M J, Bose S, Chon S Y, Cook B I. Assessing the evolving fragility of the global food system. Environmental Research Letters, 2015; 10(2): 024007.

[21] Fader M, Gerten D, Krause M, Lucht W, Cramer W. Spatial decoupling of agricultural production and consumption: quantifying dependences of countries on food imports due to domestic land and water constraints. Environmental Research Letters, 2013; 8(1): 014-046.

[22] Rakotoarisoa M A, Iafrate M, Paschali M. Why has Africa become a net food importer? Explaining Africa agricultural and food trade deficits. Rome, FAO, 2011.

[23] MacDonald G K, Brauman K A, Sun S, Kimberly C M, Cassidy E S, Gerber J S, et al. Rethinking agricultural trade relationships in an era of globalization. BioScience, 2015; 65(3): 275-289.

[24] Boers T M, Ben-Asher J. A review of rainwater harvesting. Agric.Water Manage, 1982; 5: 145-158.

[25] Critchley W, Siegert K, Chapman, C, Finkel M. Water Harvesting. A manual for the design and construction of water harvesting schemes for plant production. FAO, Rome, 1991.

[26] Falkenmark M, Fox P, Persson G, Rockstrom J. Water harvesting for upgrading of rainfed agriculture. Problem analysis and research needs. Stockholm International Water Institute, Report 11, Sweden, 2001.

[27] Humphreys E, Bayot R S. Increasing the productivity and sustainability of rainfed cropping systems of poor smallholder farmers. In book: Increasing the Productivity \& Sustainability of Rainfed Cropping Systems of Poor Smallholder Farmers, Chapter: Agricultural technology adoption successes and failures in Ghana and Kenya, Publisher: CGIAR Challenge program on water \& food, Editors: E. Humphreys \& R. S. Bayot, 2009; pp. 293-306.

[28] Rockstrom J, Barron J, Fox P. Rainwater management for increased productivity among smallholder farmers in drought prone environments. Phys. Chem. Earth, 2002; 27: 949-959.

[29] Temesgen M. Conservation tillage systems and water productivity. Implications for smallholder farmers in semi-arid Ethiopia. PhD thesis. Taylor \& Francis/Balkema, Leiden, Netherlands, 2007.

[30] Wani S P, Rockström J, Oweis T, editors. Rainfed Agriculture: Unlocking the Potential, CABI, 2009.

[31] Rockström J, Falkenmark M. Agriculture: Increase water harvesting in Africa. Nature News. Crit. Rev. Plant Sci., 2000; 19: 319-346.

[32] Food and Agriculture Organization of the United Nations. Irrigation in Africa in Figures AQUASTAT Survey. Edited by Karen Frenken FAO Land and Water Development Division. Food and Agriculture Organization of the United Nations Rome, FAO Water Reports 29, 2005.

[33] Future Agricultures; WP119, June 2015. Irrigation for Agriculture Transformation. Available online: https://www.jica.go.jp/jicari/ publication/booksandreports/175nbg0000004aet-tt/175nbg0000004ai9.pd f. Accessed on [2018-01-13]

[34] FAO Aquastat 2010. Irrigation in Central Asia in Figures. Available online: http://www.fao.org/3/a-i3289e.pdf. Accessed on [2017-12-07]

[35] FAO Aquastat 2005. Irrigation in Africa in Figures. Available online: https://www.amazon.com/29-Irrigation-Figures-Aquastat-Reports/dp/92 51054142. Accessed on [2017-12-03]

[36] Food and Agriculture Organization of the United Nations. The state of the world's land and water resources for food and Agriculture (SOLAW) - Managing systems at risk. Food and Agriculture Organization of the United Nations, Rome and Earthscan, London, 2011.
[37] World Bank. 2013. Transforming Agriculture in the Sahel: What Would It Take? Available online: http://preventionweb.net/go/35360. Accessed on [2017-12-07]

[38] International Water Management Institute 2007. A Comprehensive Assessment of water management in Agriculture. Available online: http://www.iwmi.cgiar.org/assessment/files_new/synthesis/Summary_Sy nthesisBook.pdf. Accessed on [2017-11-20]

[39] Namara R E, Horowitz L, Kolavalli S, Kranjac-Berisavljevic G, Dawuni B N, Barry B, et al. Typology of irrigation systems in Ghana. Colombo, Sri Lanka: International Water Management Institute, 2010; 35p. IWMI Working Paper 142. doi: 10.5337/2011.200

[40] Namara RE, Horowitz L, Nyamadi B, Barry B. Irrigation Development in Ghana: Past Experiences, Emerging Opportunities, and Future Directions. GSSP Working Paper No. 0026. International Food Policy Research Institute, 2011.

[41] Lakhiar I A, Gao J M, Syed T N, Chandio F A, Tunio M H, Ahmad F, et al. Overview of the aeroponic agriculture - An emerging technology for global food security. Int J Agric \& Biol Eng, 2020; 13(1): 1-10.

[42] McBratney A, Whelan B, Ancev T. Future directions of precision agriculture. Precision Agriculture, 2005; 6: 7-23.

[43] Whelan B M, McBratney A B. Definition and interpretation of potential management zones in Australia, In Proceedings of the 11th Australian Agronomy Conference, Geelong, Victoria, Feb. 2-6, 2003.

[44] Reina G. A multi sensor robotic platform for ground mapping and estimation beyond the visible spectrum. Precision Agriculture, 2018; 20(2): 423-444.

[45] Evenson R E, Pray C E, Rosegrant M W. Agricultural research and productivity growth in India. Research Report 109. Washington, DC: IFPRI, 1999.

[46] Morris M, Cervigni R, Guo Z, Koo J. The Central Role of Drylands in Africa's Development Challenge. In Cervigni R and Morris M, eds. Confronting Drought in Africa's Drylands: Opportunities for Enhancing Resilience. Washington, DC: World Bank, 2015.

[47] Riddell P J, Westlake M. Demand for products of irrigated agriculture in subSaharan Africa. Rome, Italy: FAO, 2006.

[48] Fuglie K O. Total factor productivity in the global agricultural economy: Evidence from FAO data. In J. Alston, B. Babcock, and P. Pardey, editors. The Shifting Patterns of Agricultural Production and Productivity Worldwide. Ames, IA: Midwest Agribusiness Trade and Research Information Center, 2015.

[49] You L, Ringler C, Nelson G, Wood-Sichra U, Robertson R, Wood S, et al. What is the irrigation potential for Africa? A combined biophysical and socioeconomic approach. IFPRI Discussion Paper, 00993. Washington, DC: IFPRI, 2010.

[50] Li H F, Qi Z M, Gui D W, Zeng F J. Water use efficiency and yield responses of cotton to field capacity-based deficit irrigation in an extremely arid area of China. Int J Agric \& Biol Eng, 2019; 12(6): 91-101.

[51] Food and Agriculture Organization of the United Nations. 2014. Success stories on climate smart agriculture. Rome, Italy: FAO. http://www.fao.org/3/a-i3817e.pdf. Accessed on [2017-11-26]

[52] Shideed K, Alary V, Laamari A, Nefzaoui A, El-Mourid M. Ex-post impact assessment of natural resource management technologies in crop-livestock systems in dry areas of Morocco and Tunisia. In Waibel H, Zilberman D (Ed.), International research on natural resource management: Advances in impact assessmen.t. Wallingford: FAO and CABI International, 2007; pp. 169-195.

[53] Keating B A, Carberry P, Bindraban P S, Senthold A, Meinke H, Dixon J. Eco-efficient agriculture: Concepts, challenges, and opportunities. Crop Science, 2010; 50: s1-s11.

[54] IFAD. Climate change and food security: Innovations for smallholder agriculture. EC, IFAD, CGIAR, November 2015.

[55] Zhu M, Zhou X Q, Zhai Z F. Research progresses in technological innovation and integration of agricultural engineering. Int J Agric \& Biol Eng, 2016; 9(6): 1-9.

[56] Yang G, He X L, Li X L, Long A H, Xue L Q. Transformation of surface water and groundwater and water balance in the agricultural irrigation area of the Manas River Basin, China. Int J Agric \& Biol Eng, 2017; 10(4): 107-118. 